\title{
CONF-871147-- 6
}

For publication in the Proceedings of the 19S7 ILS Conference

(Advances in Laser Science - III), Atlantic City, NJ, November 1-5, 1987

to be published by the American Institute of Physics

\section{Absolute Rate Measurements of Two-Photon Process of Gases, Liquids, and Solids}

\author{
C. H. Chen, M. P. McCann, and M. G. Payne \\ Chemical Physics Section, Oak Ridge National Laboratory \\ Post Office Box X \\ Oak Ridge, Tennessee 37831-6378 \\ Telephone (615) 574-5895
}

CONF-871147--6

DE88 003800

December 1987

Research sponsored by the Office of Health and Environmental Research

U.S. Department of Energy under contract DE-AC05-84OR21400 with Martin Marietta Energy Systems, Inc.

\section{DISCLAIMMER}

"The submitted manuscript has been authored by a contractor of the U.S. Government under contract DEAC05-84OR21400. Accordingly, the U.S. Government retaing a nonexclusive, royalty-free license to publish or reproduce the published form of this contribution, or allow others to do so, for U.S. Govermment purposes."
This report was prepared as an account of work sponsored by an agency of the United States Government. Neither the United States Government nor any agency thereof, nor any of their employees, makes any warranty, express or implied, or assumes any legal liability or responsibility for the accuracy, completeness, or usefulness of any information, apparatus, product, or process disclosed, or represents that its use would not infringe privately owned rights. Reference herein to any spexific commercial product, process, or service by trade name, trademark, manufacturer, or otherwise doss not necessarily constitute or imply its endorsement, recommendation, or favoring by the United States Government or any agency thereof. The views and opinions of authors expressed nerein do not necessarily state or reflect those of the United States Government or any agency thereof.

\section{MASTER}




\title{
ABSOLUTE RATE MEASUREMENTS OF TWO-PHOTON PROCESS
} OF GASES, LIQUIDS, AND SOLIDS

\author{
C. H. Chen, M. P. McCann, and M. G. Payne \\ Chemical Physics Section, Oak Ridge National Laboratory \\ Oak Ridge, Tennessee 37831-6378
}

Due to rapid improvements in high-power laser performance, two-photon absorption processes have become a very useful tool for studying the molecular structures of various gases, liquids and solids. However, measurements of absolute two-photon absorption cross sections were more or less ignored previously because of their small size. In this work, we obtained not only the two-photon absorption spectra, but also measurements of their absolute cross sections for various gases, liquids, and solids.

Resonance ionization spectra with the two-photon absorption process to various excited states for $\mathrm{Ar}, \mathrm{Kr},{ }^{1,2} \mathrm{H}_{2}, \mathrm{Xe}^{3} \mathrm{NO}, \mathrm{CO},{ }^{4}$ and $\mathrm{ArNO}$ were obtained. By combining a coherent vacuum ultraviolet (VIV) beam; which was produced by a third harmonic generation process in a Xe cell, two-photon absorption and three-photon ionization spectra for $\mathrm{Ar}, \mathrm{Kr}$, and $\mathrm{H}_{2}$ were obtained. Another process combining either two ultraviolet (UV) or one UV photon plus one visible photon was used for exciting various states of $\mathrm{Xe}, \mathrm{CO}, \mathrm{NO}$, and ArNO. Vibronic state-selected molecules and van der Waals molecules were produced by a rare gas seeded nozzle beam. A mass spectrometer was used to detect the ions by resonance ionization spectroscopy (RIS).

The experimental schematic for two-photon resonance excitation of $\mathrm{CO}$ is shown in Fig. 1. The two-photon absorption process promotes $\operatorname{CO}\left(X^{1} \Sigma^{+}\right)_{v=0}$ to $\operatorname{CO}\left(A^{1} \pi\right)_{v=1}$, a blue laser beam excites $\operatorname{CO}\left(A^{1} \pi\right)_{v=1}$ to $\operatorname{CO}\left(B^{1} \Sigma^{+}\right)_{v=0}$. The 
$\operatorname{CO}\left(B^{1} \Sigma^{+}\right)$molecules can be ionized by the UV beam which proceeds the twophuton excitation. The two-photon absorption cross section of $\operatorname{CO}(X)_{\nu=0} \rightarrow$ $C O(A)_{v=1}$ obtained was $2.2 \times 10^{-47} \mathrm{~cm}^{4} \mathrm{sec} \mathrm{mol}^{-1}$ and the ionization cross sections of $\operatorname{CO}\left(B^{1} \Sigma^{+}\right)_{v=0}$ was determined to be $1.4 \times 10^{-20} \mathrm{~cm}^{2}$. Molecular term energies for these two transitions were determined as follows:

$$
\begin{gathered}
\Delta E\left(J, J^{\prime}\right)=66227.9+1.577 J^{\prime}\left(J^{\prime}+1\right)-0.346 J(J+1) \\
\text { for } \\
C O(X)_{v=0} \stackrel{2 h \nu}{\longrightarrow} C O(A)_{v=1}, \\
\Delta E\left(J^{\prime}, J^{\prime \prime}\right)=20688+1.948 J^{\prime \prime}\left(J^{\prime \prime}+1\right)-1.577 J^{\prime}\left(J^{\prime}+1\right) \\
\qquad \text { for } \\
C O(A)_{v=1} \stackrel{h \nu}{\longrightarrow} C O(B)_{v=0}
\end{gathered}
$$

Similar types of experiments were also performed in other gases.

Two-photon induced fluorescence spectra were obtained to study the excitation and decay mechanism for dyes, ${ }^{5}$ neat benzene, toluene, xylene isomers, and polysubstituted methyl benzenes. By measuring the absolute number of fluorescent photons, two-photon absorption cross sections and two-photon induced fluorescence cross sections for aromatic compounds were obtained. The results are shown in Table I.

In addition, two-photon induced fluorescence spectra of various alkali halide crystals were obtained, ${ }^{6,7}$ and the mechanism for formation and decay of $\mathrm{V}_{K}$ centers as well as F-centers were studied. The two-photon absorption cross sections and the fluorescence yields due to two-photon absorption were measured. 
The formation of F-centers for certain alkali halide crystals can be conveniently used to determine the band gaps of these crystais. ${ }^{8}$

Research sponsored by the Office of Health and Environmental Research, U.S. Department of Energy under contract DE-AC05-84OR21400 with Martin Marietta Energy Systems, Inc. M. P. McCann is a graduate student, University of Tennessee, Knoxville, Tennessee.

\section{REFERENCES}

1. M. P. McCann, C. H. Chen, and M. G. Payne, Appl. Spectrosc. $\underline{41}, 399$ (1987).

2. M. P. McCann, C. H. Chen, and M. G. Payne, Chem. Phys. Lett. $\underline{138}, 250$ (1987).

3. C. H. Chen, G. S. Hurst, and M. G. Payne, Chem. Phys. Lett. $\underline{75}, 473$ (1980).

4. W. R. Ferrell, C. H. Chen, M. G. Payne, and R. D. Willis, Chem. Phys. Lett. $\underline{97}, 460$ (1983).

5. C. H. Chen and M. P. McCann, Opt. Commun. $\underline{63}, 338$ (1987).

6. C. H. Chen, M. P. McCann, and J. C. Wang, Solid State Commun. $\underline{61}, 559$ (1987).

7. C. H. Cheri and M. P. McCann, Chem. Phys. Lett. 126, 54 (1986).

8. C. H. Chen and M. P. McCann, Opt. Commun. 60, 196 (1986). 


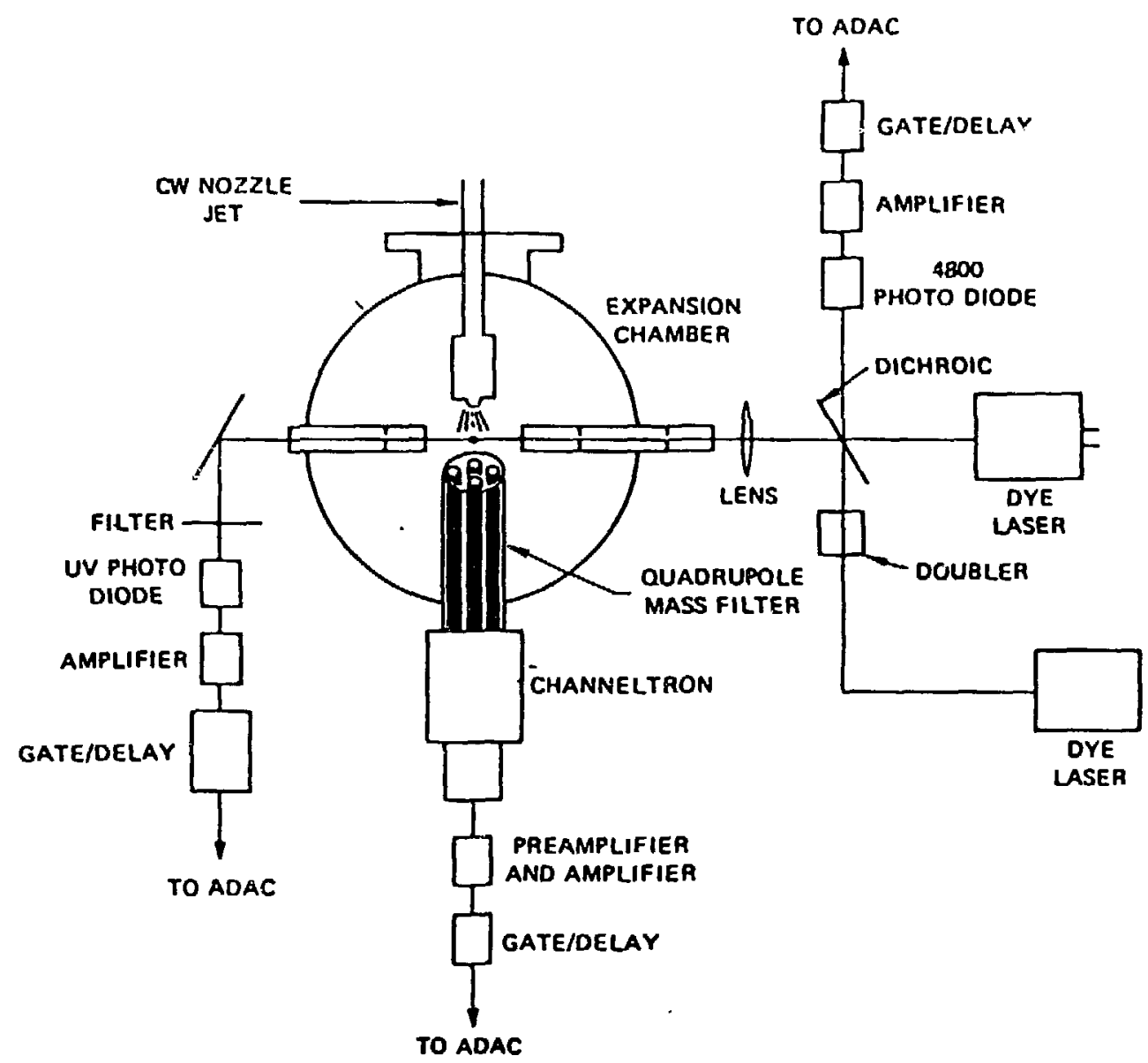

Figure 1. Data acquisition scheme. The two dye lasers are pumped by a Lumonics Nd:YAG laser. The "doubler" is the KDP crystal with appropriate red filter. 
Table I. Two-photon absorption cross sections $(\delta)$ and two-photon induced fluorescence cross sections $\left(\delta_{F}\right)$ for benzene, toulene, and xylene.

The unit of $\delta$ and $\delta_{F}$ is $\mathrm{cm}^{4} \mathrm{sec} \mathrm{mol} \mathrm{moton}^{-1}$.

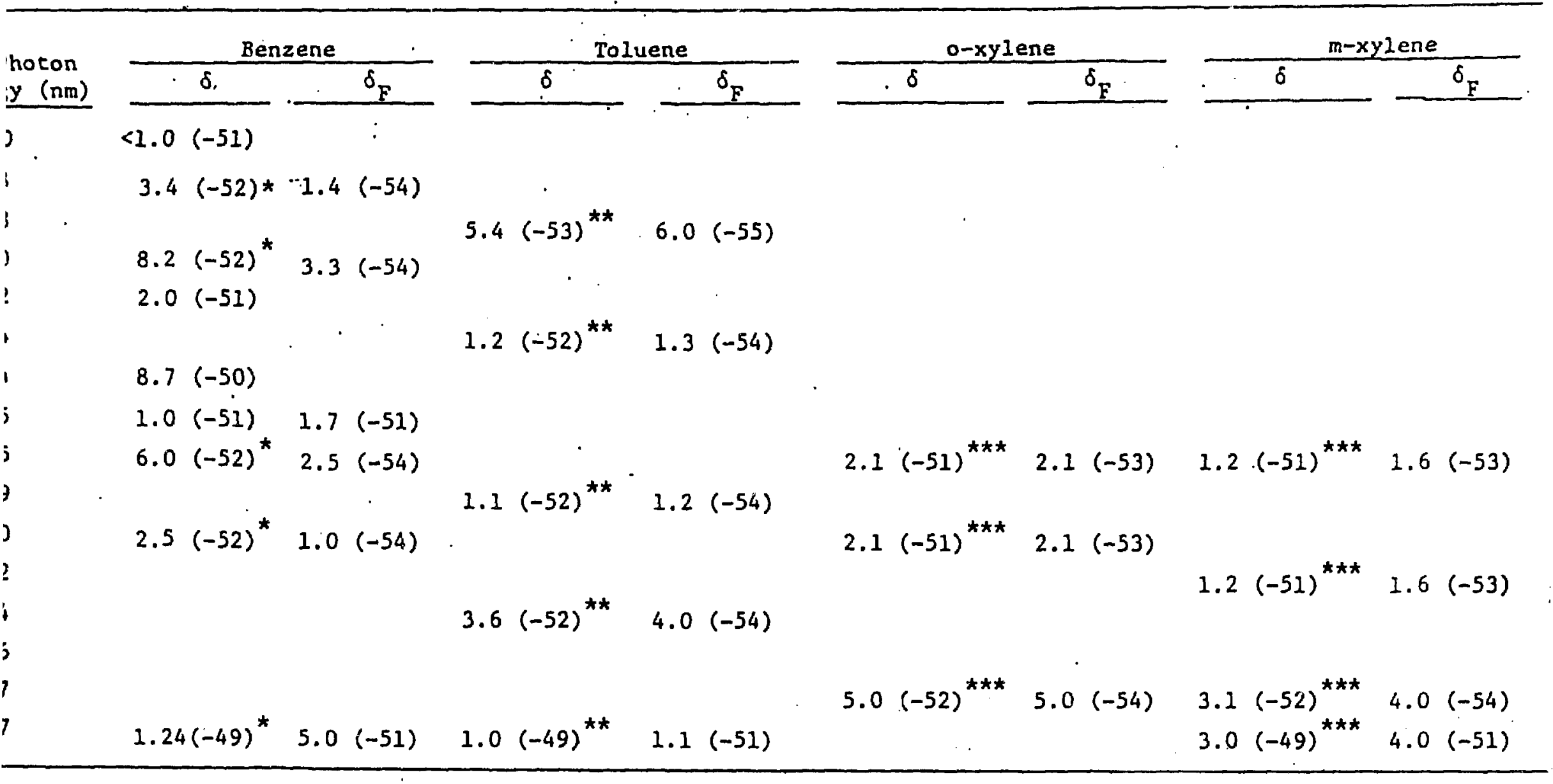

- represents $\delta$ obtained from the assumption of $\eta_{F}$ of benzene is 0.004

- represents $\delta$ obtained assuming $n_{F}$ is 0.011 for toluene

- represents $\delta$ obtained by the assumption of $n_{F}$ equal to $0.01,0.013$, and 0.01 . for o-xylene, and m-xylene, reapectively. 